\title{
p-ISSN 2622-2027 \\ $e$-ISSN 2622-2035 \\ TECHNICAL SRATEGY IN ADDRESSING THE PERCEPTION AND PARTICIPATION OF THE SOCIETY ON HEAVY METAL POLLUTION IN NGIPIK LAKE KEBOMAS GRESIK
}

\author{
Ummu Aliyah ${ }^{1}$, Mohammad Hariyadi ${ }^{2}$ \\ ${ }^{1,2}$ Industrial Engineering - Faculty of Engineering \\ Sekolah Tinggi Teknik Qomarudin \\ E-mail : umualiy@yahoo.co.id
}

\begin{abstract}
Cadmium $(C d)$ is one type of heavy metals that is harmful because these elements are at high risk of blood vessels, cadmium affects humans over long periods of time and can accumulate in the body especially the liver and kidneys, Some researchers have proved the contamination of heavy metals occurring in Ngipik Lake, so that is feared is the human body exposure to environmental pollution caused by consuming fish from this pond. Telaga Ngipik, originally a former clay mine land owned by PT. Semen Gresik. The land area of 2,250 M2 that has been exploited the mining of lime material for raw materials was dredged and left the puddle or hole that turned into a lake. Through the environmental development Program of PT. Semen Gresik, this lake has turned into a tourist attraction for local residents, but also used as fishing place, children's play area, water ski, as well as raw materials for drinking water. Perda No. 10 tahun 2010 on green Open Space arrangement has set up Telaga Ngipik including the Green Line of Lake borders. It was further strengthened in the P2KH (Green City development Program) to set up a green open space starting from 2012 where the management of this green open space involved the community and private participation in the RAKH (Green City Action Plan).
\end{abstract}

Key words : Perception analysis; community participation; heavy metal pollution (Cd), Telaga Ngipik

\section{INTRODUCTION}

Pollution that occurs in Ngipik Lake either directly or indirectly affect the health of the community because of its function as a tourism place, especially fishing fish and water resources of drinking water treatment. Because the object is the user community Ngipik itself is certainly due to pollution of heavy metals will be entered into human organs at high risk to disorders of the blood vessels, as well as the failure of liver and kidney function (Palar 2004). The analysis of perception and participation of people in addressing heavy metal pollution in Ngipik Pond is certainly necessary considering the dangers that will be inflicted both in terms of health and the handling of pollution itself.

This research will emphasize the socio-cultural side of the community around Ngipik Lake which is affected because one of its functions besides the tourist attractions is as a fishing place and the processing of raw water resources. The general research methods used in this study are case study methods. Variable which is in the study involving social culture around the area of Ngipik Kebomas Gresik Pond is covering the perception and participation of people in addressing heavy metal pollution in Ngipik pond. In general, the data collection techniques used in the research of social aspects of this community culture are field observation techniques, interviews and secondary data collection (triangulation approach). The sampling techniques used for the perception and participation of this community are the selected techniques (purpose sampling) in which the samples are chosen and determined according to the specified criteria.

The analytical method used in the study is the description analysis method, 


\section{Tibuana}

Journal of applied Industrial Engineering-University of PGRI Adi Buana

which is the method of explaining the condition of the study object according to certain criteria so that it can actually happen at the research site. Community participation and perception is analyzed using quantitative deskriftive methods. For measuring community perception is the method of Likert scale and Community Perception Index (IPM). In general, the people in the area around Ngipik Gresik Lake are many who do not understand the danger resulting from the contamination of this lake, because until now fishing activities around Ngipik Lake is still crowded by hobbyists. More on holidays. Then the water installation in Ngipik Lake until now also still operating.

\section{RESEARCH METHODOLOGY}

\section{A. Type of Researcher}

Research is a case study with field research design. An approach to qualitative descriptive research describing what is about variables, symptoms, as well as the state of perception and participation of the community in addressing heavy metal pollution in Ngipik pond. Data analysis results are expressed in the description of phenomena. This type of research is an appropriate way to reveal and interpret the perception and participation of people affected by lake Ngipik pollution. The research subject can be found by choosing the informant to be the "Key informant" in the data retrieval in the field (Sukardi,1995:7-8). In this study, the subject of research was (1) the community around Ngipik Pond, (2) Fishing fish, (3) the Management of Industrial District (KIG) Gresik (4) Gresik Environmental Agency (5) PT. Semen Indonesia. As for the object in this study is the perception and participation of the community in addressing heavy metal pollution in Ngipik pond. The study was also directed to meet the following criteria; 1) credibility; A) triangulation, B) talks with colleagues (peer debrieving), c) Use of reference material, D) hold a member check. 2) transferability; A) The dependability and confirmability, b) records and records as complete as possible interviews, observations, or documentation studies as raw data for subsequent purposes, c) compile the results of the analysis by structuring the raw data later Summarizing or rearranging in the form of a systematic description, D) Create an attachment or conclusion as a result of data synthesis, and E) Report the entire research process from survey and drafting to data processing as Described in the research report. 


\section{Tibuana}

\section{B. Research Procedure}

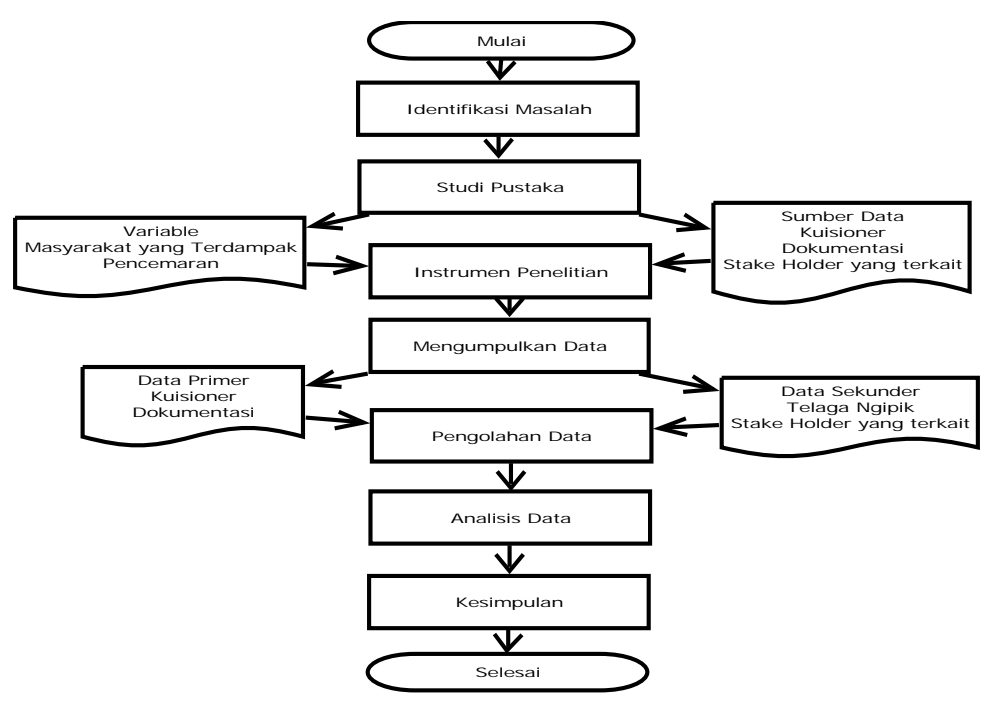

Figure.1. Research Procedure

As per figure 1 above, in this research procedure there are several phases that researchers do which include:

\section{Orientation Stage}

Orientation is preliminary research to obtain a more complete picture of the problem to establish focus of the research. Prior to the research in the field, researchers first prepared the administrative requirements as an early stage to be able to enter the research area, cover letter of research from the campus, application of permits from the district Industry and respondent information.

\section{Phase exploration}

This stage is done with the aim of collecting data pertaining to focus and research purposes, after all the licensing requirements are met. After that intensively researchers collect data and information done through community interviews. The interview in order to obtain this data and information was taken through an agreement between the researcher and the respondent in order to have the intention of the depth of the research be achieved well. Every subsequent interview result is made a description based on the questions sub topic. It is possible to simplify the process of data analysis coupled with supporting documents at the time of field research.

\section{The Member stage of Check Phase}

The final stage in the implementation of the research, namely to verify by checking the validity or correctness of data and information that has been collected. The purpose of this activity is carried out to the results of the research is more trustworthy, and the information or data checking is done every time the researcher finished the interview, which is taken by confirming the records of interviews with the Respondent every time the interview was done. To support and solidify again the data and information that has been obtained, there are also observations and documentation studies and "triangulation" to respondents and other competent sources of data. Therefore, the implementation time of the member check is done along with the exploration stage.

\section{RESULTS AND DISCUSSION}

\section{A. Community Perception}

In addressing the perception of society, it is necessary to look at the cause of pollution from pollutants against Ngipik 


\section{Tibuana}

Journal of applied Industrial Engineering-University of PGRI Adi Buana

wells from TPA Ngipik or KIG outlet channels originating from the factory area and channels Household waste. In addition, the attitude of the fishermen who are affected directly and indirectly from this pollution should be in response to the questions circulated to the respondents. The answer to the respondent's question is arranged so that it can be answered in five tiers of Likert scale.

From the assumptions above, there are several criteria of statement used to measure public perception of pollution that occurs in Ngipik pond as follows:

1. Pollution Ngipik Pond because the disposal factor from the factory waste.
2. Pollution disposal of household waste from the upstream of the channel leading to Ngipik Pond

3. Pollution caused by the waste seepage Lindi from TPA Ngipik

4. Management of waste disposal from less restrictive kig management.

5. The unexplained implementation of Perda No. 10 year 2010 which regulate the status of Lake Ngipik as RTH.

6. Ngipik Pond Natural Facilities that are an attraction for anglers.

Of the 6 types of questioner submitted to the respondent, the Likert chart where the number $5=$ very agreed $/$ good, $4=\operatorname{good}, 3=$ enough, $2=$ less, $1=$ very less.

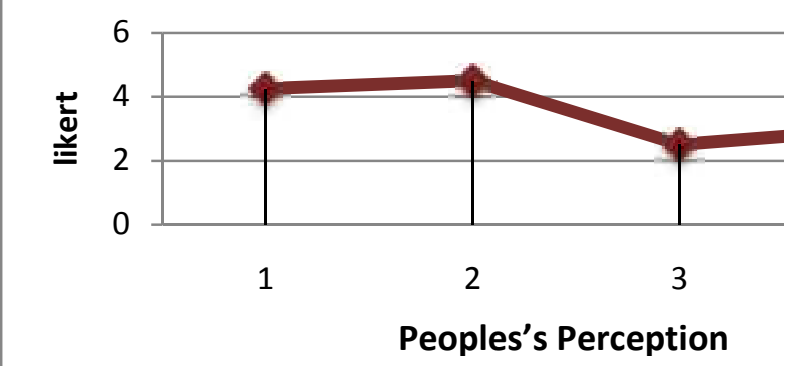

Figure 2. Community perception

Although the results of the study showed that there is pollution derived from the outlet channel KIG, but there is a place where the waste disposal (IPAL) installation makes the community think that not all existing companies around the KIG waste their waste Outlet. Many are still aware to dispose of waste through IPAL. This is seen from the high value of the scale of Likert according to community perception. Instead, the community considers the Perda that regulates the status of Lake Ngipik which is lacking socialization, so the participation to take part in this case is lacking. Beside that, easy access to Ngipik pond with various supporting facilities as well as waste seepage from TPA Ngipik which is a towing of waste contact in the community who consume fish catch. Besides, the community also expects the rules of disposal of waste from the factory to the IPAL that has been made by the KIG to be more tightened. So that the waste flowing into the outlet channel can be minimalized.

\section{B. Community Participation.}

The level of community participation in environmental management is measured using the participation Index (IP) of Stuart Chapin (1952). While for the degree of community involvement is measured by the participation instruments of Arnstein (1969) which is known by eight stairs of participation in society. The form of 


\section{Tibuana}

Journal of applied Industrial Engineering-University of PGRI Adi Buana

$p$-ISSN 2622-2027

$e$-ISSN 2622-2035

community participation is the contribution of energy, mind, time and funds devoted to the planning, implementation, and supervision of environmental conservation activities. Heavy metal pollution in Ngipik pond during this time its handling is still not significant, everything goes overlap, which means that each stake holder involved is busy with his own business. While the community also does not understand what to do to be involved in overcoming pollution. During this time involved in Ngipik pond pollution is still limited to research researchers from ITS, Khairul Yadi et al, only limited to convey the result of pollution information, then research from ITATS also added test results against Ngipik pond pollution.

Paguyuban community that exists around Ngipik Lake called NMFC reveals their ignorance of Ngipik lake status which has changed function to green land based on Perda No. 10 year 2010 on green Open Space arrangement, Ngipik Lake includes a green strip of Lake boundary. It was further strengthened in the P2KH (Green City development Program) to set up a green open space starting from 2012 where the management of this green open space involved community and private participation in the RAKH (Green City Action Plan). Their assumption is that the Ngipik pond belongs to PT. Semen Indonesia. The result of the research on the level of community participation according to the program provided by the Ngipic Lake stakeholders showed that the achievement index varies according to existing stakeholders with an index range between $0.50-1.00$. The index value of 1 indicates that the degree of community participation is high, in the sense that the position of participation is in the 8th step of participation ladder, where the community is actively involved in the supervision of activities. The value of the participation index less than 1 implies that the degree of community participation is still low.

The average community participation index is 0.59 or within the range of 0.50 0.60 . This means the degree of community 
other words, the community is made equal partners to equally implement the program. However, again the partnership in the field is still in the conceptual landscape yet implemented. Communities seem to be positioned as partners but in fact their positions are not aligned in the process of retrieval and execution of decisions. Public NGOs NMFC, and government agencies, $\mathrm{KIG}$, DLH, its participatory index value is 0.50 . This means that the degree of community participation in Ngipik Lake Normalization program offered/initiated by the institutional is on the fourth ladder, the consultation phase. In other words, the community in the program is only consulted.

\section{CONCLUSION}

Less clearly his implementation of Perda No. 10 year 2010 about the arrangement of green open space according to the perception of the community becomes irregular his water that enters Ngipik lake which causes pollution, besides also the presence of water line Lindi from TPA Ngipik. Then a good infrastructure facility facilitates the polluted lake in the human body through fish fishing activities. Another factor according to respondents is the obligation to dispose of waste to a less stringent IPAL so that there is a factory that removes the toxic waste to Ngipik pond.

In general, of all the pollution control programs that have been conducted by the stakeholder component to date, the average community participation index is 0.59 or within the range of $0.50-0.60$. This means, the degree of community participation in the Mangrove rehabilitation program is still low because it is less than 1. According to the Ladder Arnstein pollution control program in the efforts to preserve the Ngipik lake is at the stage of information and consultation or the level of "tokenism" that is a level of participation where society is heard and May argue, but they have no ability to get assurance that their views will be considered by the decision holders.

\section{ACKNOWLEDGMENT}

This research can be done on the grant Fund from KEMENRISTEKDIKTI, the fore will be published further research on the prevention of pollution itself that is more incoming to external which is more concrete Implementation of the relevant agencies.

\section{REFERENCES}

1. Candra I., 2012. Partisipasi masyarakat dalam pengelolaan sampah rumah tangga (Studi kasus di Kelurahan Siantan Tengah Kecamatan Pontianak Utara), Sociodev-Jurnal Ilmu Sosiatri. 1(1):1-21. [terhubung berkala]. http://jurnalmahasiswa.fisip.

untan.ac.id .index.php/jurnalsosiatri/article/view/ 140. [9 Oktober 2013].

2. Khairul Yadi dkk. (2017), Deteksi Persebaran Air Lindi Menggunakan Inversi VLF-EM Studi Kasus TPA Ngipik,Jurnal Geosaintek, 03/02 Tahun 2017.

3. Prihadi dan Wahyono Hadi (2018), Analisis Pencemaran Sebagai Acuan Perumusan Strategi Teknis Pemulihan Kualitas Air dI Telaga Ngipik Kebomas Gresik Prosiding Seminar Nasional KK RALC ITB 2018, No. ISBN: 978-602-52152-00.

4. Peraturan Menteri Negara Lingkungan Hidup No..03 tahun 2010, Baku Mutu Limbah Bagi Kawasan Industri.

5. Peraturan Menteri Kesehatan Republik Indonesia No. 492 Tahun 2010 tentang Persyaratan Kualitas Air Minum. 


\section{Tibuana}

Journal of applied Industrial Engineering-University of PGRI Adi Buana

p-ISSN 2622-2027

$e$-ISSN 2622-2035

6. PP No. 85/1999 tentang Perubahan PP No. 18/1999, Direvisi Peraturan terbaru yang mengatur mengenai B3 yakni PP No. 74 Tahun 2001 tentang Pengelolaan Bahan Berbahaya dan Beracun.

7. SK Gubernur Jawa Timur No. 45 Tahun 2002 tentang Baku Mutu Limbah Cair Bagi Industri atau Kegiatan Usaha Lainnya di Jawa Timur. 